\title{
PERANCANGAN APLIKASI IT HELPDESK BERBASIS WEB DI PT. PANCA ABADI NAN JAYA
}

\author{
Abdurahman Fauzi ${ }^{1}$, Asep Topan Suryadi ${ }^{2}$ \\ 1 Universitas Adhirajasa Reswara Sanjaya \\ e-mail: kakangfauzi85@gmail.com \\ ${ }^{2}$ Universitas Adhirajasa Reswara Sanjaya \\ e-mail: tofansuryadi@gmail.com
}

\begin{abstract}
Abstrak
Dalam perusahaan, Helpdesk merupakan sebuah bagian atau departement yang melakukan proses untuk mengumpulkan data dari berbagai sumber yang ada dan dituntut untuk aktif melayani dan menanggapi kebutuhan pengguna. Perkembangan Helpdesk diharapkan dapat mengatasi permasalahan dan memberikan layanan terhadap seluruh permasalahan baik yang bersifat internal maupun seluruh permasalahan operasional aplikasi ataupun hal-hal yang berhubungan dengan sistem dan teknologi informasi. Helpdesk merupakan bantuan informasi yang menangani permasalahan atau troubleshooting. Sistem Helpdesk Informasi Teknologi pada PT. Panca Abadi Nan Jaya saat ini yang digunakan hanya menggunakan email, telepon dan aplikasi android yaitu what'sapp. Bila ada suatu masalah yang berkaitan dengan perangkat IT, pihak user langsung menghubungi IT melalui telepon atau what'sapp. Tetapi ada keluhan dari user apa permasalahan nya sudah di kerjakan atau belum dikerjakan, karena pihak IT terkadang lupa memberi informasi ke pihak user apakah keluhan nya sudah di kerjakan atau belum oleh pihak IT. Maka dari itu penulis mencoba merancang sistem aplikasi IT Helpdesk berbasis Web. Hasil aplikasi Helpdesk mampu mempersingkat waktu pengolahan data, mengurangi masalah human error dalam proses pencatatan data, menghasilkan laporan-laporan helpdesk dengan cepat dan akurat, serta diharapkan dapat membantu proses pengambilan keputusan perusahaan.
\end{abstract}

Kata Kunci : Helpdesk, Troubleshooting, Web

\begin{abstract}
In a company, Helpdesk is a part or department that carries out a process to collect data from various existing sources and is required to actively serve and respond to user needs. The development of the Helpdesk is expected to be able to overcome problems and provide services to all problems both internal and all application operational problems or matters relating to information systems and technology. Helpdesk is information assistance that handles problems or troubleshooting. Information Technology Helpdesk System at PT. Panca Abadi Nan Jaya currently used only uses email, telephone and an android application that is what's app. If there is a problem related to IT devices, the user directly contacts IT via telephone or what's app. But there are complaints from users whether the problem has been done or not yet done, because IT sometimes forgets to give information to the user whether the complaint has been done or not by the IT. Therefore the writer tries to design a Web-based IT Helpdesk application system. The results of the Helpdesk application are able to shorten data processing time, reduce human error problems in the data recording process, produce helpdesk reports quickly and accurately, and are expected to help the company's decision making process
\end{abstract}

Keywords: Helpdesk, Troubleshooting, Web 


\section{Pendahuluan}

Perkembangan teknologi informasi yang sedemikian cepatnya telah membawa dunia memasuki era baru yang lebih cepat dari yang pernah dibayangkan sebelumnya. Setidak-tidaknya ada empat era penting sejak ditemukannya komputer sebagai alat pengolah data sampai dengan era internet saat komputer menjadi senjata utama dalam berkompetensi (Indrajit, 2013). Dalam perusahaan, Helpdesk merupakan sebuah bagian atau departement yang melakukan proses untuk mengumpulkan data dari berbagai sumber yang ada dan dituntut untuk aktif melayani dan menanggapi kebutuhan pengguna. Adapun Helpdesk bertujuan untuk menindaklanjuti permasalahan atau keluhan teknis yang dihadapi pengguna(Verawati, 2018)

Perkembangan

Helpdesk

diharapkan dapat mengatasi permasalahan dan memberikan layanan terhadap seluruh permasalahan baik yang bersifat internal maupun seluruh permasalahan operasional aplikasi ataupun hal-hal yang berhubungan dengan sistem dan teknologi informasi. Helpdesk merupakan bantuan informasi yang menangani permasalahan atau troubleshooting. Fasilitas Helpdesk banyak digunakan oleh perusahaan atau instansi untuk memberikan solusi secara cepat dan memberikan kemudahan bagi pengguna atau internal perusahaan (Cassandra, 2015.).

Sistem Helpdesk Informasi Teknologi pada PT. Panca Abadi Nan Jaya saat ini yang digunakan hanya menggunakan email, telepon dan aplikasi android yaitu what'sapp. User bila ada suatu masalah yang berkaitan dengan perangkat IT, pihak user langsung menghubungi IT melalui telepon atau what'sapp. Tetapi ada keluhan dari user apa permasalahan nya sudah di kerjakan atau belum dikerjakan, karena pihak IT terkadang lupa memberi informasi ke pihak user apakah keluhan nya sudah di kerjakan atau belum oleh pihak IT. Dengan adanya keluhan dari user, IT mencoba menerima semua keluhan itu. Dengan adanya sistem informasi IT Helpdesk pada PT. Panca Abadi Nan Jaya, penulis mencoba merancang sistem IT Helpdesk Informasi Teknologi berbasis web. Pembangunan suatu websiteyang dinamis dapat digunakan untuk mengembangkan eHelpdeskyang dibutuhkan sebagai sistem dukungan teknis. Sedangkan sebuah websiteadalah kumpulan halaman webyang saling terkait dan biasanya disimpan di dalam komputer web server (Dean, 2018) Untuk kelebihan web ini, dapat membantu user membuat formulir suatu permasalahan langsung terkirim ke IT Helpdesk PT. Panca Abadi Nan Jaya, dapat mengontrol semua pekerjaan IT dalam suatu permasalahan yang berkaitan dengan perangkat Informasi Teknologi, dapat membantu menyusun laporan pekerjaan IT, dapat membantu pihak manajemen mengambil keputusan dengan melihat suatu masalah yang berkaitan dengan Informasi Teknologi.

Sistem adalah kumpulan dari beberapa bagian tertentu yang saling berhubungan secara harmonis untuk mencapai suatu tujuan tertentu. Elemenelemen yang mewakili sistem secara umum adalah masukan (input) pengolahan (processing) dan keluaran (output) (Sutopo, Cahyadi, \& Arifin, 2016).

Perancangan atau desain didefinisikan sebagai proses aplikasi berbagai teknik dan prinsip bagi tujuan pendefenisian suatu perangkat, suatu proses atau sistem dalam detail yang memadai untuk memungkinkan ralisasi fisiknya (Abdullah, Herawati, \& Herliana, 2015).

Oleh karena itu, berdasarkan permasalahan yang diuraikan diatas maka dibuatlah aplikasi IT Helpdesk ini.

\section{Metode Penelitian}

Penelitian ini dilakukan untuk memperoleh data dan informasi yang dibutuhkan, menurut Sugiyono (2013) teknik pengumpulan data merupakan langkah yang paling strategis dalam penelitian maka metode yang digunakan dalam proses pengumpulan data adalah

\section{Observasi}

Penulis melakukan pengamatan langsung terhadap obyek-obyek yang ada pada perusahaan untuk mendapatkan datadata yang dibutuhkan penulis untuk keperluan penelitian di perusahaan PT. Panca Abadi Nan Jaya.

2. Wawancara

Teknik wawancara yaitu, suatu metode pengumpulan data dengan melakukan Tanya jawab sepihak yang dilakukan secara sistematis dan berlandaskan kepada tujuan penelitian, yaitu dengan melakukan wawancara kepada perusahaan PT. Panca Abadi Nan Jaya. 


\section{Studi Pustaka}

Metode penelitian yang digunakan pengumpulan data dengan membandingkan research pada jurnal yang sejenis dengan judul penelitian yang berhubungan dengan masalah yang dimuat dalam penelitian ini.

\subsection{Metode Pengembangan Aplikasi}

Dalam proses pengembangan aplikasi penelitian yang dilakukan di PT. Panca Abadi Nan Jaya, peneliti menggunakan metode waterfall, menurut Rosa dan Shalahudin (2013) tahapan waterfall sebagai berikut :

1. Tahap analisis kebutuhan perangkat lunak

2. Tahap desain

3. Tahap pembuatan kode program

4. Tahap pengujian

5. Tahap pendukung (support) atau pemeliharaan (maintenance)

\section{Hasil dan Pembahasan}

Berikut merupakan hasil dan pembahasan untuk pembuatan Sistem IT Helpdesk berbasis website ini. dimana user bisa melakukan laporan permasalahan berkaitan dengan seluruh sumber daya IT melalui website yang sudah disediakan dan dapat diakses melalui internet, tidak hanya itu ada 3 user atau pengguna yaitu admin, teknisi, dan user (petugas yang melaporkan tiket). Berikut ini usulan kebutuhan sistem dari perancangan aplikasi IT Helpdesk berbasis web di PT. Panca Abadi Nan Jaya yang akan di rancang :
1. Halaman Admin :

A.1. Admin melakukan login.

A.2. Admin dapat mengelola data tiket.

A.3. Admin dapat melihat semua tiket yang diajukan.

A.4. Admin dapat menambahkan klasifikasi permasalahan tiket.

A.5. Admin dapat melihat laporan teknisi.

2. Halaman User / Staff :

B.1. User melakukan login.

B.2. User dapat membuat tiket baru.

B.3. User dapat melihat semua tiket yang diajukan.

B.4. User dapat melihat tiket yang sudah selesai.

3. Halaman Teknisi :

C.1. Teknisi dapat login

C.2. Teknisi dapat melihat semua tiket yang diajukan.

C.3. Teknisi dapat melihat tiket yang sudah selesai.

\subsection{Use Case}

Menurut Sukamto, Ariani dan Shalahudin (2015) Use Case atau diagram Use Case merupakan pemodelan untuk melakukan (behavior) sistem informasi yang akan dibuat. Berikut merupakan gambaran Use Case diagram yang terdiri dari Use Case diagram halaman admin, halaman user (staff) dan halaman teknisi :

1. Use Case Diagram IT Helpdesk Halaman Admin : 


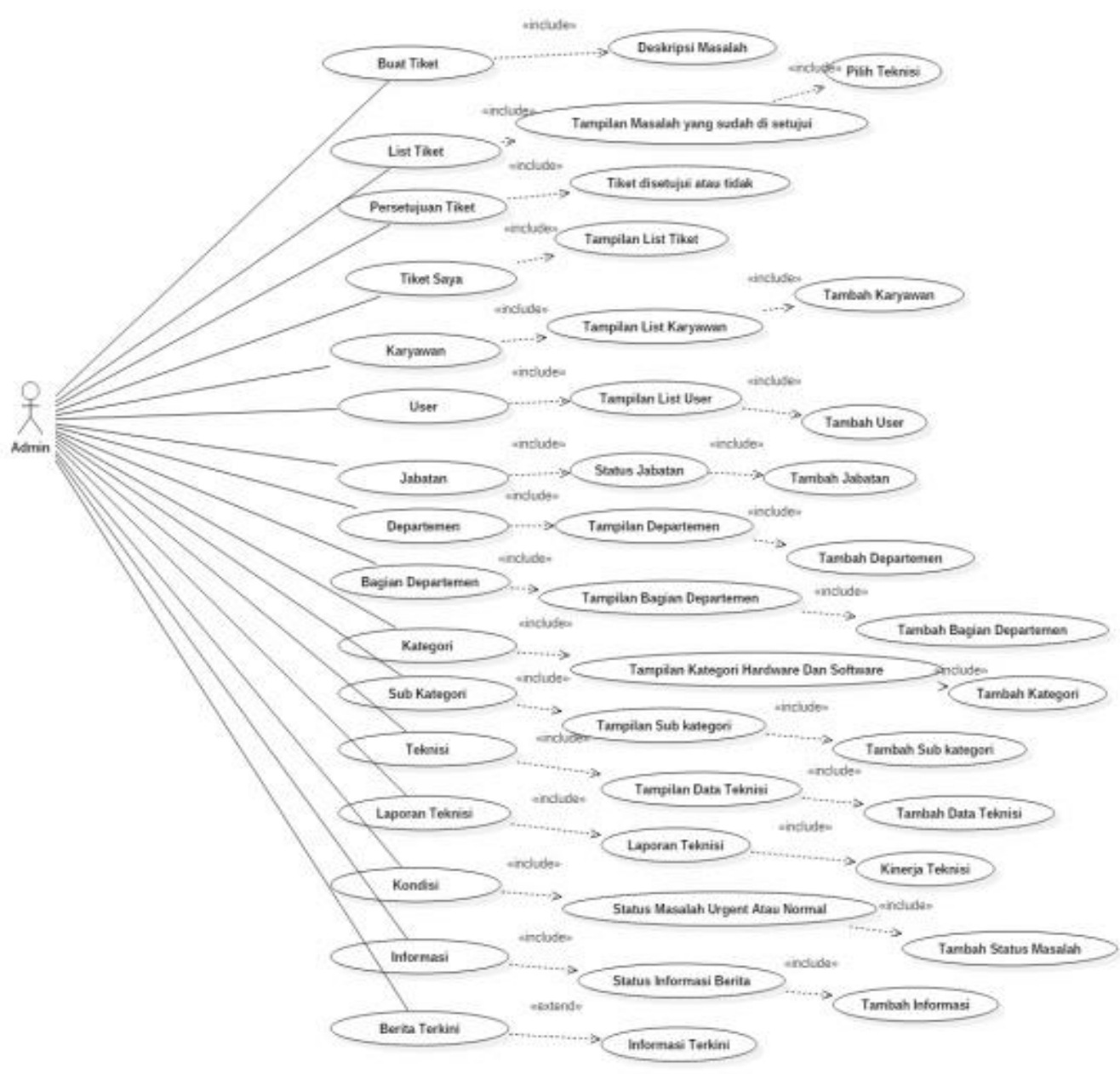

Gambar 1. Use Case Diagram IT Helpdesk Halaman Admin 2. Use Case Diagram IT Helpdesk

Halaman User

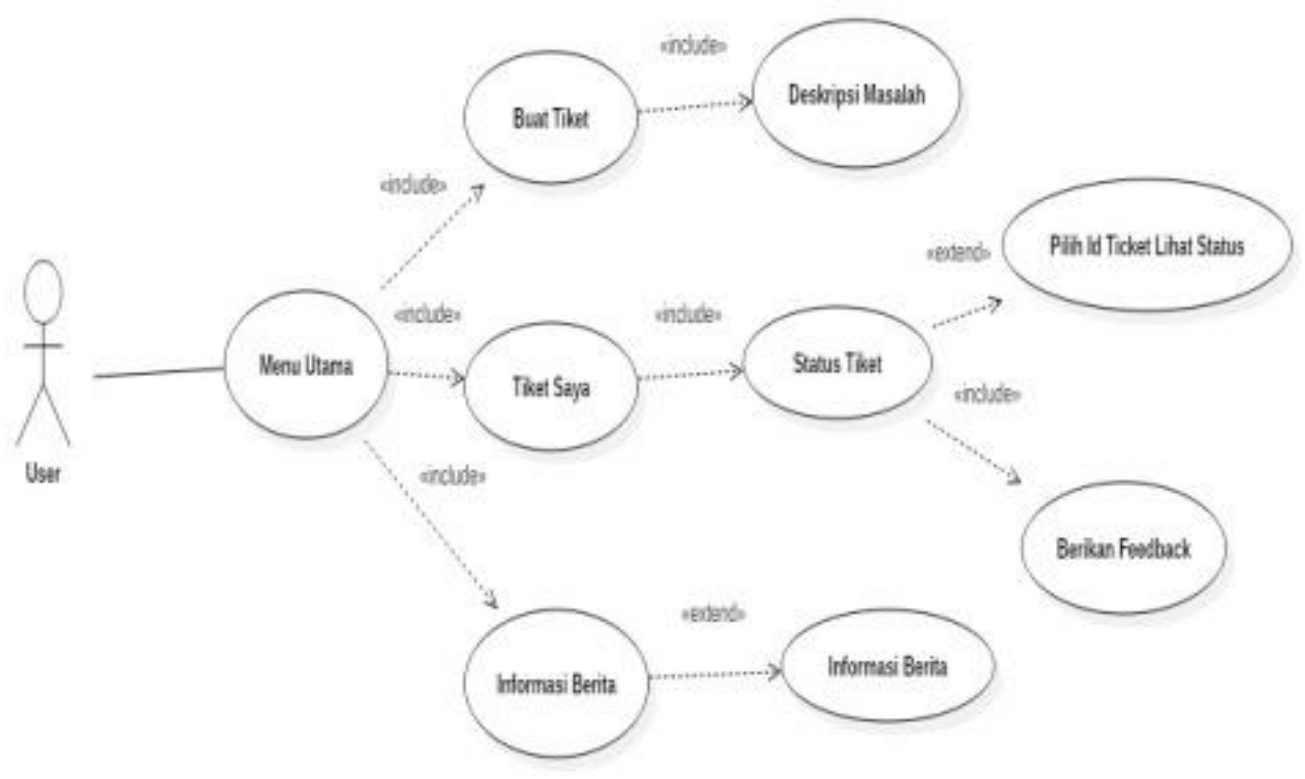

Gambar 2. Use Case Diagram IT Helpdesk Halaman User 


\subsection{User Interface}

Menurut Lastiansyah (2012) User Interface adalah cara program dan pengguna berinteraksi. Dalam istilah User Interface terkadang digunakan sebagai pengganti istilah Human Computer
Interacktion $(\mathrm{HCl})$ dimana semua aspek dari interaksi pengguna dan komputer

Berikut adalah rancangan antar muka pengguna yang memperlihatkan bagaimana bentuk dari perangkat lunak yang akan dibangun nantinya berdasarkan struktur aplikasi yang sudah dibuat.
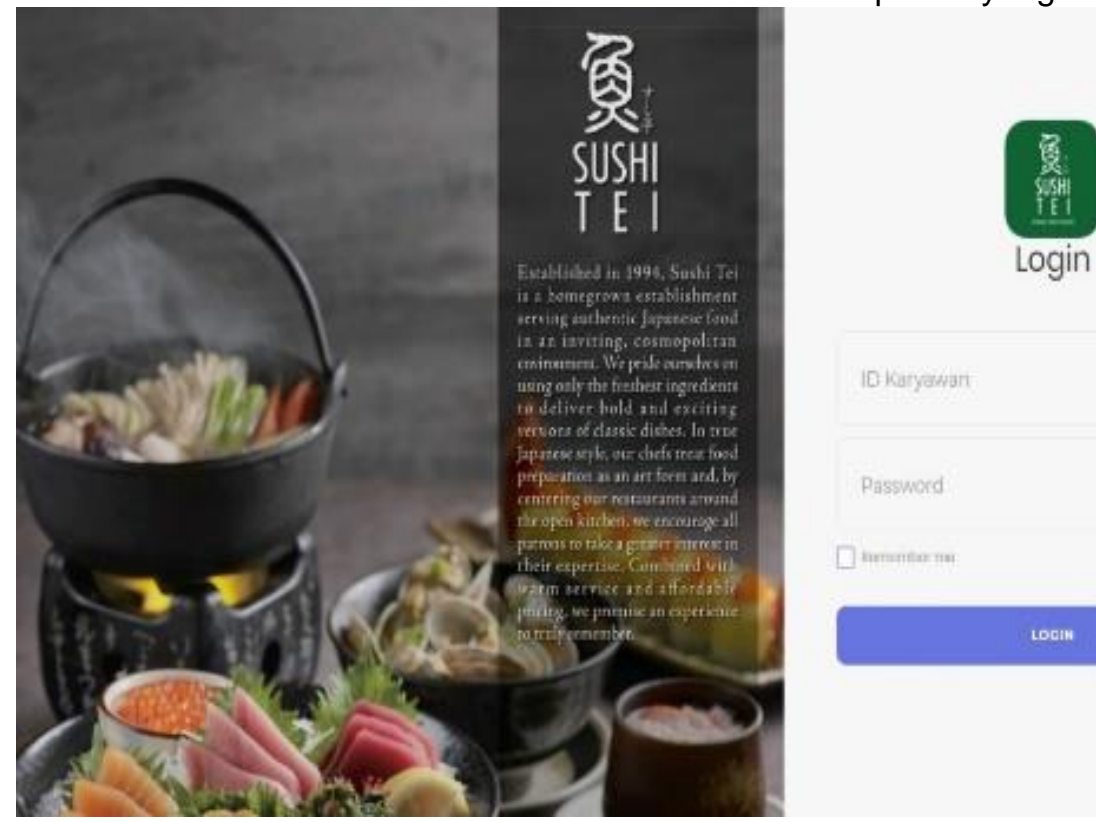

Gambar 3. Form Login

Dalam hal ini setiap user (admin, sudah dibedakan berdasarkan hak teknisi dan user) mempunyai tampilan aksesnya.

halaman login admin yang sama hanya saja

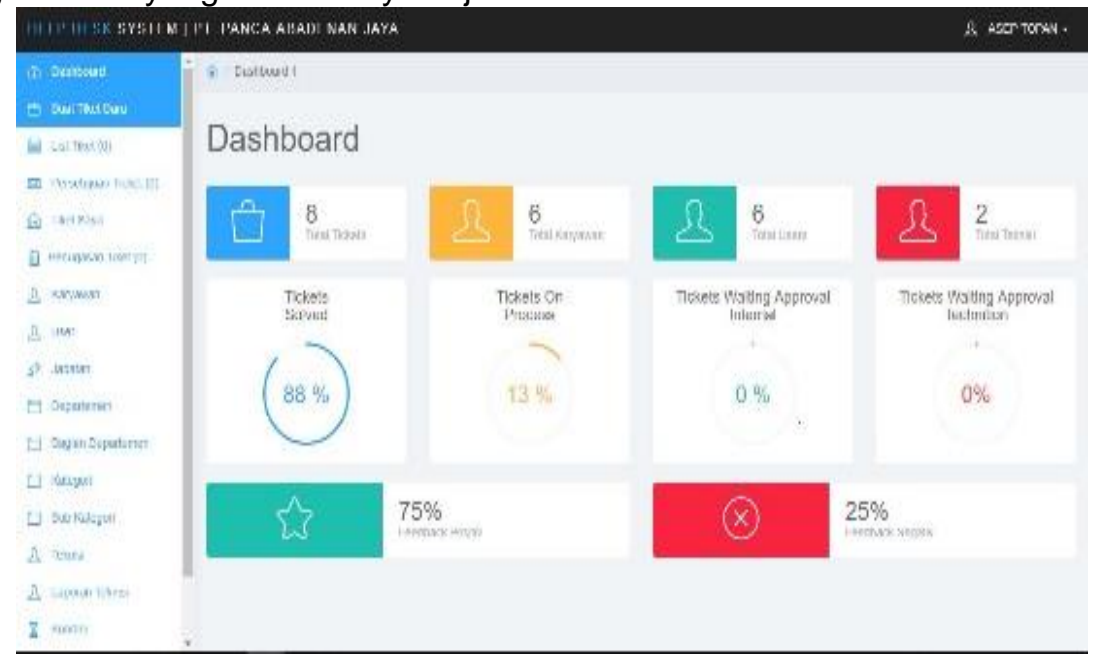

Gambar 4. Dashboard Admin

Terlihat dalam gambar tersebut banyak sekali menu pada sidebar kiri hal ini dikarenakan admin adalah super user dimana admin bisa mengatur akses yang ada di teknisi dan user. 


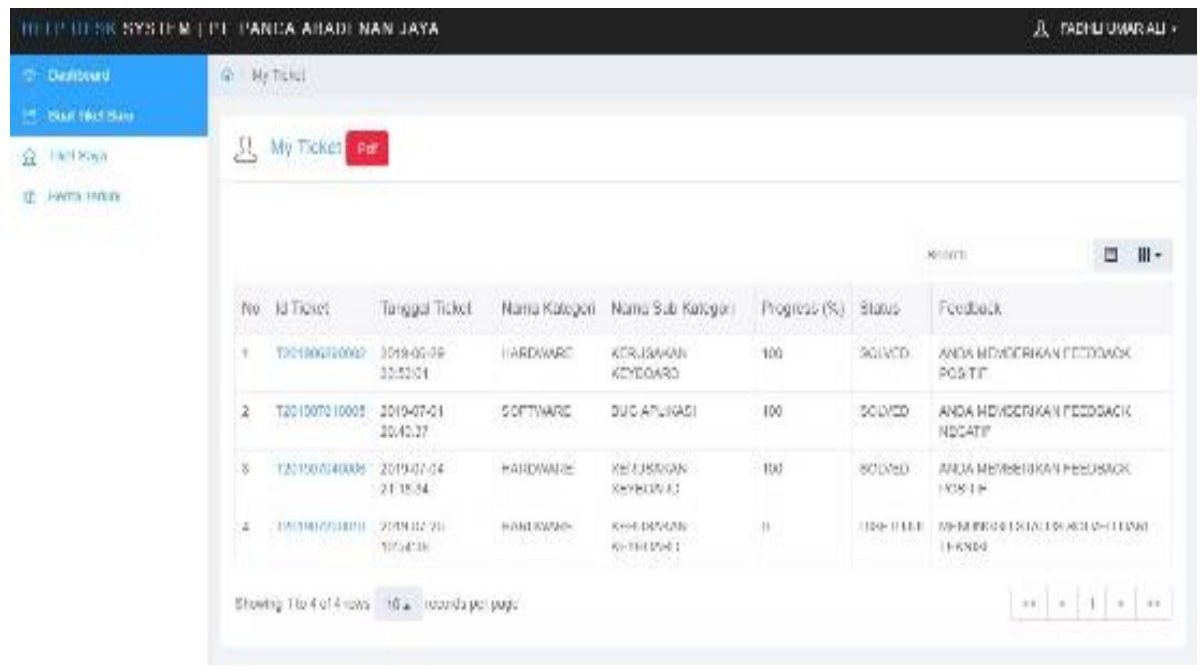

Gambar 5. Halaman List Tiket

Dalam gambar diatas adalah halaman yang ada pada user yaitu sebagai seseorang yang melaporkan tiket yang nantinya akan di validasi oleh admin dan akan di teruskan kepada teknisi untuk dilakukan proses selanjutnya.

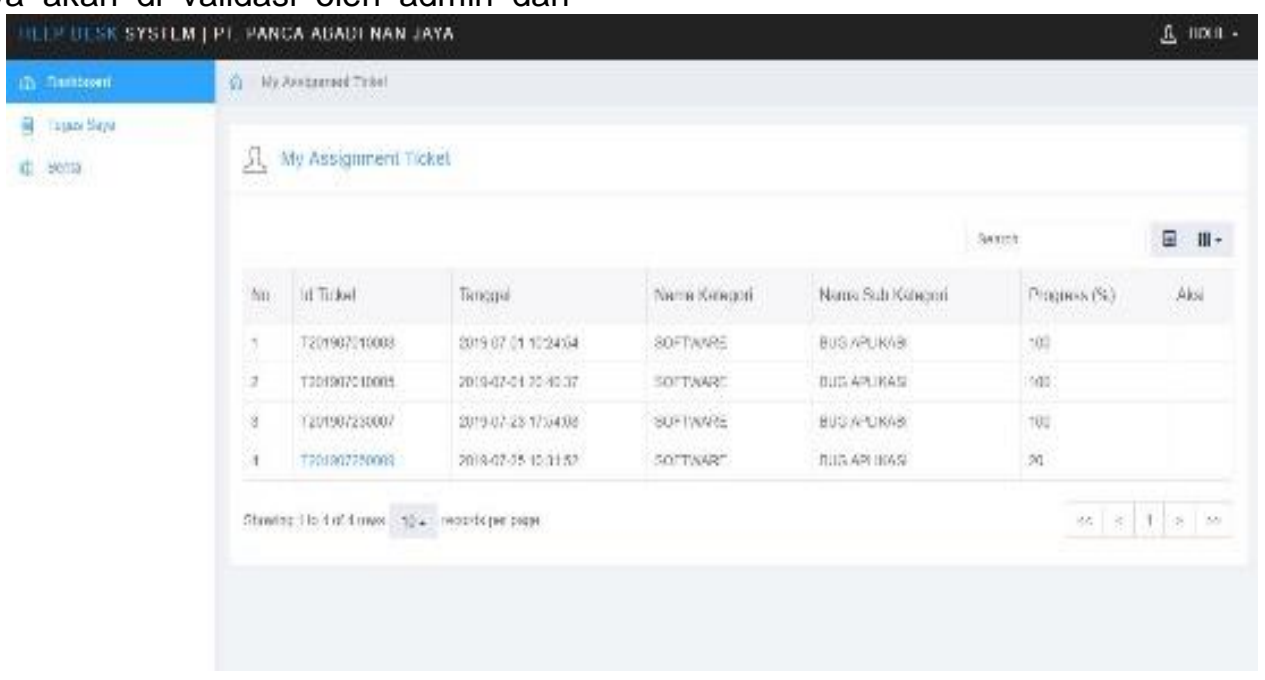

Gambar 6. Halaman List Tugas Teknisi

Seperti yang penulis jelaskan sebelumnya bahwa teknisi bertugas memantau tiket yang sudah dilaporkan oleh user yang sudah di validasi oleh admin untuk dilakukan proses troubleshoot.

\section{Kesimpulan}

Berdasarkan pembahasan yang dilakukan, penulis dapat menarik kesimpulan bahwa pada PT. Panca Abadi Nan Jaya memiliki beberapa masalah dalam melaporkan keluhan-keluhan yang berhubungan dengan teknologi informasi dan sistem yang berjalan masih menggunakan email ataupun telpon, sehingga mempersulit dalam melihat hasil laporan dari setiap keluhan-keluhan yang sudah terjadi. Maka dari itu, penulis mengusulkan sebuah sistem aplikasi IT Helpdesk. Berdasarkan analisis, perancangan dan implementasi program, dapat disimpulkan sebagai berikut :

1. Terkontrolnya kebutuhan sistem informasi untuk User ke IT dan sebaliknya. 
2. Terkontrolnya masalah yang dilaporkan User ke IT.

3. Dapat membuat laporan bulanan pekerjaan IT.

4. Mempermudah untuk mengontrol pekerjaan IT.

Saran

Dari kesimpulan pada penelitian ini, maka penulis memberikan masukanmasukan yang bisa menjadi pedoman agar penggunaan aplikasi tersebut berjalan lancar serta bermanfaat bagi perusahaan. Adapun saran yang ingin penulis sampaikan adalah sebagai berikut:

1. Penambahan dalam sistem yang dapat kirim email saat user mengirim permasalahan.

2. Penambahan menu live chat, menu ini di buat agar memudahkan interaksi antara admin, staff dan teknisi.

3. Perlu dibuatkan adanya pemeliharaan program dan database baik dari serangan virus dari hal lain yang dapat merusak serangan database.

\section{Referensi}

Abdullah, D. H. \& H. (2015). Perancangan Sistem Informasi Pendataan Siswa SMP Islam Swasta Darul Yatama Berbasis Web, 4(1), 39-44.

Cassandra, C. (n.d.). PENGEMBANGAN MODEL SISTEM INFORMASI APLIKASI HELPDESK ONLINE PT . MUSTIKA MEMADATA, 173-184.

Dean, J. (2018). web programming with html5, css, and javascript. Jones \& Bartlett Learning.

Indrajit, R. E. (2013). Evolusi Perkembangan Teknologi Informasi, 7(C), 1-7.

Lastiansah. 2012. Penelitian Tindakan Kelas. CV. Bandung : Yrama.

Rosa, A.S dan Shalahuddin, M. 2013. Rekayasa Perangkat Lunak Terstruktur dan Berorientasi Objek. Bandung: Informatika Bandung

Sugiyono. 2013. Metode Penelitian Kuantitatif, Kualitatif Dan R\&D. Bandung: CV. Alfabeta.

Sukamto Ariani, R., \& Shalahuddin, M. (2015). REKAYASA PERANGKAT LUNAK TERSTRUKTUR dan BERORIENTASI OBJEK. Bandung: Informatika Bandung.

Sutopo, P., Cahyadi, D., \& Arifin, Z. (2016). SISTEM INFORMASI EKSEKUTIF SEBARAN

PENJUALAN
KENDARAAN BERMOTOR RODA 2 DI KALIMANTAN TIMUR BERBASIS WEB, 11(1).

Verawati, L. (2018). P E R AN G K AT L U N A K H E L P DE S K T I C K E T I NG BERBASIS WEB DI PT MEPROFARM BANDUNG, 11(2). 